\title{
Clonal Rearrangements and Malignant Clones in Peripheral T-cell Lymphoma
}

\author{
Yu. V. Sidorova', N. G. Chernova', N. V. Ryzhikova', S. Yu. Smirnova', M. N. Sinicina', \\ Yu. E. Vinogradova², H. L. Julhakyan', A. M. Kovrigina', E. E. Zvonkov', A. B. Sudarikov ${ }^{1 *}$ \\ ${ }^{1}$ National Hematology Research Center of the Ministry of Health, Novy Zykovski lane 4a, 125167, \\ Moscow, Russia \\ 2.M. Sechenov Moscow State Medical University, Department of Hospital Therapy №2, \\ B. Pirogovskaya, 4, 119435 Moscow, Russia \\ *E-mail: dusha@blood.ru \\ Received: 24.03.2015 \\ Copyright $\odot 2015$ Park-media, Ltd. This is an open access article distributed under the Creative Commons Attribution License, which permits \\ unrestricted use, distribution, and reproduction in any medium, provided the original work is properly cited.
}

\begin{abstract}
Aim: To assess the feasibility and informative value of T-cell clonality testing in peripheral T-cell lymphoma (PTCL). Patients and methods: Biopsies of involved sites, blood, and bone marrow samples from 30 PTCL patients are included in the study. Rearranged TCRG and TCRB gene fragments were PCR-amplified according to the BIOMED-2 protocol and analyzed by capillary electrophoresis on ABI PRISM 3130 (Applied Biosystems). Results: TCRG and TCRB gene clonality assay was valuable in confirming diagnosis in $\mathbf{9 7 \%}$ of PTCL patients. T-cell clonality assay performed on blood or bone marrow samples reaffirmed lymphoma in $93 \%$ of cases, whereas morphological methods were informative in $\mathbf{7 3 \%}$ of cases only. We observed multiple TCRG and TCRB gene rearrangements, loss of certain clones in the course of the disease, as well as acquisition of new clones in 63\% of PTCL cases, which can be attributed to the genetic instability of the tumor. Conclusion: TCRG and TCRB gene clonality assay is beneficial for the diagnosis of PTCL. However, the presence of multiple clonal rearrangements should be considered. Clonal evolution in PTCL, particularly acquisition of new clones, should not be treated as a second tumor. Multiple $T C R G$ and $T C R B$ gene rearrangements may interfere with minimal residual disease monitoring in PTCL.

KEYWORDS peripheral T-cell lymphoma, PCR, gene rearrangement of $\mathbf{T}$ cell receptor, T-lymphocytes clonality. ABBREVIATIONS PTCL-NOS, peripheral T-cell lymphoma, not otherwise specified; TCR, T-cell receptor; TCRG, T-cell receptor gamma; TCRB, T-cell receptor beta; TCRD, T-cell receptor delta; CD, cluster of differentiation.
\end{abstract}

\section{INTRODUCTION}

Peripheral T-cell lymphoma, not otherwise specified (PTCL-NOS) is a heterogeneous group of lymphomas with a mature immunophenotype of peripheral (postthymic) T-lymphocytes. This diagnosis covers more than $29 \%$ of $\mathrm{T}$-cell lymphomas that do not belong to other nosological forms and is a diagnosis by exclusion $[1,2]$. Clinically, the disease is aggressive (five-year overall survival rate is less than $32 \%$ ), often advanced (69\% of patients are diagnosed at stages III/IV) with extranodal sites being involved (bone marrow, skin, subcutaneous tissue, and lungs) [3]. It is believed that the morphological substrates of the tumors are T-lymphocytes of mature T-cells immunophenotype with a $\alpha \beta$-variant of the T-cell surface receptor (TCR $\alpha \beta)$ and $\mathrm{CD} 2+, \mathrm{CD} 3+, \mathrm{CD} 5+, \mathrm{CD} 7+, \mathrm{CD} 4+$ or $\mathrm{CD} 8+$ markers, whose expression displays signs of aberrance (loss of one or more of them). Most often, PTCL-NOS has a CD4+/CD8-immunophenotype, less commonly a CD4-/CD8+ one. In some peripheral T-cell lympho- mas, the expression of T-cell markers on the surface is limited, e.g. only CD2 or CD3. In addition, a small number of PTCL-NOS are $\gamma \delta$-T-lymphocytes lymphomas that cannot be classified as hepatolienal $\gamma \delta$-lymphomas or $\gamma \delta$-variant of large granular lymphocytes leukemia based on clinical and morphological data [3-6]. A study of clonal rearrangements of T-cell receptor genes in PTCL-NOS confirms T-cell clonality in complex diagnostic cases and proves the presence of a tumor [7-11]. The method consists of PCR amplification and analysis of the genes of the $\mathrm{V}-\mathrm{D}-\mathrm{J}$-segments junction region of the T-cell receptors $\delta$ (TCRD), $\gamma(T C R G)$, and $\beta$ $(T C R B)$. This region has a unique nucleotide sequence in each normal T-lymphocyte. A fragment analysis of amplification products derived from healthy tissue reveals a lot of peaks with a Gaussian distribution of their lengths (Fig.1A). Monoclonal samples with the same length of PCR products are present as a single peak (monoallelic rearrangement, Fig. 1B) or as two peaks (biallelic rearrangement, Fig. 1B). 
The length of the monoclonal PCR product is unique for the tumor clone and is identical in all affected tissues of a patient. Detection of a clone, for example, in bone marrow aspirate, indicates bone marrow involvement. Furthermore, the nature of rearrangements can reveal the degree of a lymphoid tumor maturity. Rearrangements during normal maturation of T-lymphocytes occur in sequence: $T C R D(\mathrm{~V} \delta-\mathrm{D} \delta, \mathrm{D} \delta-\mathrm{D} \delta, \mathrm{D} \delta-\mathrm{J} \delta, \mathrm{V} \delta-\mathrm{J} \delta)$ gene locus is rearranged first, followed by $T C R G(\mathrm{~V} \gamma-\mathrm{J} \gamma)$ and incomplete rearrangement of TCRB (D $\beta-J \beta)$. Complete rearrangements of TCRB (V $\beta-\mathrm{J} \beta)$ and TCR $\alpha$-locus $(\mathrm{V} \alpha-\mathrm{J} \alpha)$ (Fig. 2) occur later [12, 13]. Since TCR $(\mathrm{TCRD})$ genes are located inside $T C R \alpha$-locus, they are cut out during $T C R \alpha$ rearrangement. Therefore, the entire range of clonal rearrangements observed in lymphomas can be divided into early and more mature ones. If a tumor contains TCRD and TCRG loci clonal products, incomplete rearrangement of $\mathrm{D} \beta-\mathrm{J} \beta$, and no complete $\mathrm{V} \beta-J \beta$ rearrangements of $T C R B$ genes, this indicates an early nature of the rearrangements, which corresponds to a tumor of $\gamma \delta$-T-lymphocytes. More commonly, a tumor has a more mature spectrum of rearrangements: $\mathrm{V} \gamma-\mathrm{J} \gamma, \mathrm{D} \beta-\mathrm{J} \beta$, and $\mathrm{V} \beta-\mathrm{J} \beta$ rearrangements present simultaneously, which is typical of most TCR $\alpha \beta$-lymphomas, including PTCL-NOS. According to published data, clonal rearrangements of the TCRG and TCRB genes are present in $81-94 \%$ and $96 \%$ of PTCL-NOS, respectively $[7,8]$.

\section{MATERIALS AND METHODS}

A retrospective analysis of clonality studies results in PTCL-NOS over the last 10 years $(2005-2015)$ has
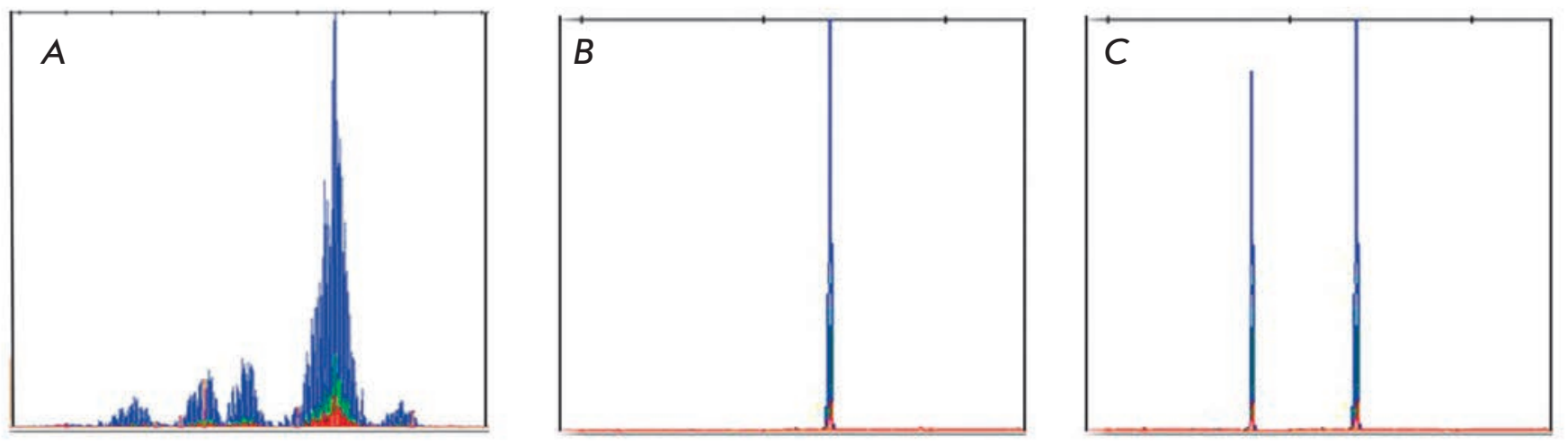

Fig. 1. Example of TCRG clonality testing: a) polyclonal, b) monoclonal (monoallelic rearrangement), c) monoclonal (biallelic rearrangement)

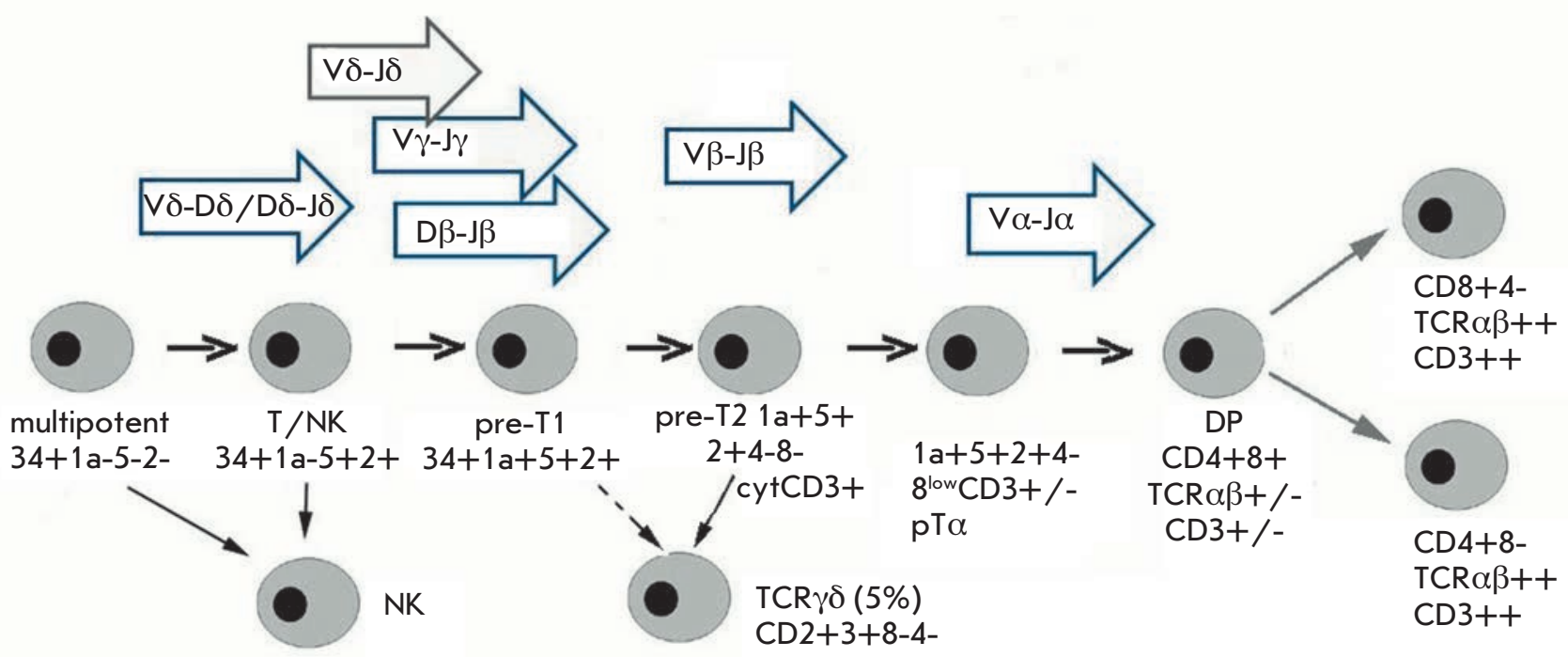

Fig. 2. Early stages of T-cell development. Sequential rearrangements in $\delta, \gamma, \beta$, and $\alpha$ chains of TCR genes. DP - double positive cells 
Table 1. Data of laboratory diagnostics

\begin{tabular}{|c|c|c|c|c|c|c|c|c|c|}
\hline \multirow[t]{2}{*}{ № } & \multirow[t]{2}{*}{$\begin{array}{l}\text { Major immunophenotypical charac- } \\
\text { teristics of the tumor }\end{array}$} & \multirow[t]{2}{*}{ Lesion volume } & \multirow[t]{2}{*}{ Stage } & \multirow[t]{2}{*}{$\begin{array}{l}\text { BMI } \\
\text { PCR }\end{array}$} & \multicolumn{3}{|c|}{$\begin{array}{l}\text { Total number of clonal } \\
\text { rearrangements *** }\end{array}$} & \multirow[t]{2}{*}{$\begin{array}{c}\text { Qty } \\
\text { clones }^{* *}\end{array}$} & \multirow[t]{2}{*}{$\begin{array}{l}\text { Qty } \\
\text { tissues } \\
\text { studied }\end{array}$} \\
\hline & & & & & $\begin{array}{l}\text { TCRG, } \\
\text { TCRD* }\end{array}$ & $\begin{array}{l}\text { TCRB } \\
\mathrm{D} \beta-\mathrm{J} \beta\end{array}$ & $\begin{array}{l}\text { TCRB } \\
\text { V } \beta-J \beta\end{array}$ & & \\
\hline 1 & $\begin{array}{l}\text { LN CD3m+CD4+CD8-CD30-GranzB- } \\
\text { CD5-CD57-CXCL13-CD7+ }\end{array}$ & $\mathrm{LN}$ & $\mathrm{I}$ & $\mathrm{nm}$ & $3 \mathrm{~V} \gamma-\mathrm{J} \gamma$ & $3 \mathrm{D} \beta-\mathrm{J} \beta$ & 0 & 2 & 1 \\
\hline 2 & $\begin{array}{c}\text { Spl CD3m+CD4+CD8+CD5+TIA- } \\
\text { 1+GranzB+CD7+CD56+ }\end{array}$ & BM Liv Spl GI & IV & + & $2 \mathrm{~V} \gamma-\mathrm{J} \gamma$ & $3 \mathrm{D} \beta-\mathrm{J} \beta$ & $1 \mathrm{~V} \beta-\mathrm{J} \beta$ & 3 & 5 \\
\hline 3 & $\begin{array}{c}\text { Spl CD3m+CD4- } \\
\text { CD8+CD2+CD7+CD30-CD10-CD5+ }\end{array}$ & BM Spl & IV & + & $\begin{array}{l}1 \mathrm{~V} \gamma-\mathrm{J} \gamma \\
3 T C R D\end{array}$ & $2 \mathrm{D} \beta-\mathrm{J} \beta$ & $5 \mathrm{~V} \beta-\mathrm{J} \beta$ & 4 & 2 \\
\hline 4 & $\begin{array}{c}\text { BM CD3m+CD4+CD8+CD10-CD1a- } \\
\text { CD5+CD7+ }\end{array}$ & BM Spl & IV & + & $6 \mathrm{~V} \gamma-\mathrm{J} \gamma$ & $4 \mathrm{D} \beta-\mathrm{J} \beta$ & $5 \mathrm{~V} \beta-\mathrm{J} \beta$ & 4 & 2 \\
\hline 5 & $\begin{array}{c}\text { BM CD3e-CD4-CD8+(part)CD7-CD2- } \\
\text { CD1a-CD5-CD56-CD30- } \\
\text { Spl CD3e+CD4-CD8-CD7-CD2- } \\
\text { CD1a-CD5-CD30-ALK-GranzB- }\end{array}$ & BM Spl & IV & + & $3 \mathrm{~V} \gamma-\mathrm{J} \gamma$ & $3 \mathrm{D} \beta-\mathrm{J} \beta$ & $3 \mathrm{~V} \beta-\mathrm{J} \beta$ & 3 & 3 \\
\hline 6 & $\begin{array}{c}\text { LN CD3m+CD4+CD8- } \\
\text { CD45RO+CD2+CD7-CD30-ALK- }\end{array}$ & BM LN & IV & + & $3 \mathrm{~V} \gamma-\mathrm{J} \gamma$ & nd & nd & 2 & 1 \\
\hline 7 & $\begin{array}{l}\text { LN CD3m+CD4-CD8+CDRO+CD30- } \\
\text { CD15-CD23-CD56- }\end{array}$ & BM LN Spl Sto & IV & + & $3 \mathrm{~V} \gamma-\mathrm{J} \gamma$ & $1 \mathrm{D} \beta-\mathrm{J} \beta$ & $2 \mathrm{~V} \beta-\mathrm{J} \beta$ & 2 & 5 \\
\hline 8 & $\begin{array}{l}\mathrm{LN} \mathrm{CD} 3 \mathrm{~m}+\mathrm{CD} 4+\mathrm{CD} 8-\mathrm{CD} 5+\mathrm{CD} 10- \\
\text { CD23- }\end{array}$ & BM LN Skin Ton & III & + & $5 \mathrm{~V} \gamma-\mathrm{J} \gamma$ & $1 \mathrm{D} \beta-\mathrm{J} \beta$ & $3 \mathrm{~V} \beta-\mathrm{J} \beta$ & 4 & 9 \\
\hline 9 & $\begin{array}{c}\text { LN CD3m+CD4- } \\
\text { CD8+CD2+CD5+CD30+ }\end{array}$ & $\begin{array}{l}\text { BM LN Skin Lar } \\
\text { Ton }\end{array}$ & IV & + & $8 \mathrm{~V} \gamma-\mathrm{J} \gamma$ & $3 \mathrm{D} \beta-\mathrm{J} \beta$ & $3 \mathrm{~V} \beta-\mathrm{J} \beta$ & 7 & 6 \\
\hline 10 & LN CD3m+CD4-CD8+CD5+TIA-1+ & $\begin{array}{l}\text { BM LN GI MG } \\
\text { Lung }\end{array}$ & IV & + & $2 \mathrm{~V} \gamma-\mathrm{J} \gamma$ & $3 \mathrm{D} \beta-\mathrm{J} \beta$ & $3 \mathrm{~V} \beta-\mathrm{J} \beta$ & 3 & 6 \\
\hline 11 & $\begin{array}{c}\text { LN CD3m+CD4+CD8- } \\
\text { CD2+CD5+CD7+CD15-CD1a- }\end{array}$ & $\begin{array}{l}\text { BM LN Lung Sto } \\
\text { Skin Liv Spl NL }\end{array}$ & III & + & $4 \mathrm{~V} \gamma-\mathrm{J} \gamma$ & $2 \mathrm{D} \beta-\mathrm{J} \beta$ & $2 \mathrm{~V} \beta-\mathrm{J} \beta$ & 5 & 7 \\
\hline 12 & $\begin{array}{l}\text { LN CD3m+CD4+CD8- } \\
\text { CD30+GranzB-EMA+ }\end{array}$ & $\begin{array}{l}\text { BM LN MG } \\
\text { Lung Ton NL }\end{array}$ & IV & + & $3 \mathrm{~V} \gamma-\mathrm{J} \gamma$ & $2 \mathrm{D} \beta-\mathrm{J} \beta$ & $1 \mathrm{~V} \beta-\mathrm{J} \beta$ & 2 & 2 \\
\hline 13 & Spl CD3m+CD4-CD8-TIA-I+ & BM Spl Liv & IV & + & $8 \mathrm{~V} \gamma-\mathrm{J} \gamma$ & $2 \mathrm{D} \beta-\mathrm{J} \beta$ & $4 \mathrm{~V} \beta-\mathrm{J} \beta$ & 4 & 4 \\
\hline 14 & $\begin{array}{c}\mathrm{LN} \\
\mathrm{CD} 3 \mathrm{~m}+\mathrm{CD} 4+\mathrm{CD} 8+\mathrm{CD} 7+\mathrm{CD} 2+\mathrm{CD} 30- \\
\mathrm{NK}-\end{array}$ & BM LN Skin & IV & + & $2 \mathrm{~V} \gamma-\mathrm{J} \gamma$ & $3 \mathrm{D} \beta-\mathrm{J} \beta$ & $1 \mathrm{~V} \beta-\mathrm{J} \beta$ & 2 & 2 \\
\hline 15 & Med CD3m+CD4+CD8-CD30-ALK- & Mediastinum & $\mathrm{IE}$ & $\mathrm{nm}$ & $2 \mathrm{~V} \gamma-\mathrm{J} \gamma$ & $1 \mathrm{D} \beta-\mathrm{J} \beta$ & $1 \mathrm{~V} \beta-\mathrm{J} \beta$ & 1 & 1 \\
\hline 16 & $\begin{array}{c}\text { Lung CD3m+CD4+CD8- } \\
\text { CD45RO+CD5+CD7+CD30-CD10- } \\
\text { CD23- }\end{array}$ & LN Lung & $\mathrm{IE}$ & + & $3 \mathrm{~V} \gamma-\mathrm{J} \gamma$ & $1 \mathrm{D} \beta-\mathrm{J} \beta$ & $2 \mathrm{~V} \beta-\mathrm{J} \beta$ & 2 & 3 \\
\hline 17 & $\begin{array}{l}\text { LN CD3m+CD4+CD8- } \\
\text { CD30+CD33+CD56- }\end{array}$ & Med LN & III & + & $3 \mathrm{~V} \gamma-\mathrm{J} \gamma$ & $2 \mathrm{D} \beta-\mathrm{J} \beta$ & $1 \mathrm{~V} \beta-\mathrm{J} \beta$ & 2 & 2 \\
\hline 18 & LN CD3m+CD4-CD8+CD5+CD7+ & $\mathrm{LN}$ & III & + & $2 \mathrm{~V} \gamma-\mathrm{J} \gamma$ & 0 & $2 \mathrm{~V} \beta-\mathrm{J} \beta$ & 1 & 2 \\
\hline 19 & $\begin{array}{l}\text { LN CD3m+CD4+CD8- } \\
\text { CD5+CD4+CD10-ALK- }\end{array}$ & LN Spl & III & $+?$ & $2 \mathrm{~V} \gamma-\mathrm{J} \gamma$ & 0 & $1 \mathrm{~V} \beta-\mathrm{J} \beta$ & 1 & 2 \\
\hline 20 & $\begin{array}{c}\text { Spl CD3c+CD4-CD8-CD1a- } \\
\text { CD2+CD5-CD7-CD4-CD8- } \\
\text { CD16+CD56+ }\end{array}$ & BM Spl & IV & + & $2 \mathrm{~V} \gamma-\mathrm{J} \gamma$ & $1 \mathrm{D} \beta-\mathrm{J} \beta$ & $2 \mathrm{~V} \beta-\mathrm{J} \beta$ & 2 & 2 \\
\hline 21 & $\begin{array}{l}\text { LN CD3m+CD4-CD8-CD30-CD15- } \\
\text { CD5+CD7+NK-CD2+GranzB- }\end{array}$ & BM LN & IV & + & $2 \mathrm{~V} \gamma-\mathrm{J} \gamma$ & $1 \mathrm{D} \beta-\mathrm{J} \beta$ & $2 \mathrm{~V} \beta-\mathrm{J} \beta$ & 2 & 2 \\
\hline 22 & $\begin{array}{l}\text { LN CD3m+CD4-CD8+CD30-CD10- } \\
\text { CD15-CD23- }\end{array}$ & BM LN & IV & + & $1 \mathrm{~V} \gamma-\mathrm{J} \gamma$ & 0 & $2 \mathrm{~V} \beta-\mathrm{J} \beta$ & 1 & 1 \\
\hline 23 & $\begin{array}{c}\text { Orbit } \\
\text { CD3m+CD4+CD8+CD5+CD7+TIA- } \\
\text { 1+CD10-CD30-CD56-LPM-1-CD23- } \\
\text { ALK- }\end{array}$ & $\begin{array}{l}\text { Soft tissues of } \\
\text { the orbirt }\end{array}$ & $\mathrm{IE}$ & $\mathrm{Nm}$ & $1 \mathrm{~V} \gamma-\mathrm{J} \gamma$ & $1 \mathrm{D} \beta-\mathrm{J} \beta$ & $1 \mathrm{~V} \beta-\mathrm{J} \beta$ & 1 & 1 \\
\hline 24 & $\begin{array}{c}\text { Spl CD3m+CD4+CD8- } \\
\text { CD2+CD5+CD7+CD56+TIA-1+ }\end{array}$ & BM Spl & IV & + & $2 \mathrm{~V} \gamma-\mathrm{J} \gamma$ & $1 \mathrm{D} \beta-\mathrm{J} \beta$ & $2 \mathrm{~V} \beta-\mathrm{J} \beta$ & 1 & 2 \\
\hline
\end{tabular}




\begin{tabular}{|c|c|c|c|c|c|c|c|c|c|}
\hline 25 & $\begin{array}{c}\text { LN CD3m+CD4+CD8- } \\
\text { CD2+CD7+GranzB+CD30-CXCL13- } \\
\text { PD1-LMP1- }\end{array}$ & Spl LN & III & - & 0 & 0 & 0 & 0 & 2 \\
\hline 26 & $\begin{array}{c}\text { LN CD3m+CD4+CD8- } \\
\text { CD2+CD5+CD7+CD30-ALK- } \\
\text { GranzB-EMA-CD56-CD57- }\end{array}$ & BM LN & IV & - & 0 & $\begin{array}{l}2 \mathrm{D} \beta-\mathrm{J} \beta \\
\text { (doubt) }\end{array}$ & $\begin{array}{l}1 \mathrm{~V} \beta-\mathrm{J} \beta \\
\text { (doubt) }\end{array}$ & 1 & 2 \\
\hline 27 & $\begin{array}{c}\text { LN CD3e-CD4-CD8-CD10-CD5- } \\
\text { CD23-CD30-ALK-JCA+CD2+CD7+ } \\
\text { GranzB- }\end{array}$ & BM LN Skin & IV & + & 0 & $\begin{array}{c}1 \mathrm{D} \beta-\mathrm{J} \beta \\
(\mathrm{BM})\end{array}$ & 0 & 1 & 3 \\
\hline 28 & $\begin{array}{c}\text { BM CD2+CD3+CD5-CD7+-CD4-CD8- } \\
\text { CD16+56+cytCD3TCR } \gamma \delta+ \\
\text { Spl CD3e+ (m+cyt) CD4-CD8-CD5-CD7- } \\
\text { TIA-I+CD56+ } \\
\end{array}$ & BM Spl & IV & + & $\begin{array}{l}2 \mathrm{~V} \gamma-\mathrm{J} \gamma \\
3 T C R D\end{array}$ & $2 \mathrm{D} \beta-\mathrm{J} \beta$ & 0 & 1 & 2 \\
\hline 29 & $\begin{array}{c}\text { Blood } \\
\text { CD3+TCR } \alpha \beta+C D 4+C D 8+C D 5+C D 7+\end{array}$ & BM Spl & IV & + & $1 \mathrm{~V} \gamma-\mathrm{J} \gamma$ & 0 & $2 \mathrm{~V} \beta-\mathrm{J} \beta$ & 1 & 1 \\
\hline 30 & $\begin{array}{l}\text { BM 30\% cellsCD3+CD4-CD8-CD5- } \\
\text { CD2+ }\end{array}$ & BM Spl & IV & + & $3 \mathrm{~V} \gamma-\mathrm{J} \gamma$ & $2 \mathrm{D} \beta-\mathrm{J} \beta$ & $1 \mathrm{~V} \beta-\mathrm{J} \beta$ & 2 & 2 \\
\hline
\end{tabular}

Note. LN, lymph node; Spl, spleen; BM, bone marrow; GI, intestine; Sto, stomach, Lar, larynx, Liv, liver; Ton, tonsils; Lung, lung; MG, mammary gland; NL, neuroleukemia; Med, mediastinum. TCRD*, the study of TCRD genes was conducted in two patients with suspicion of $\gamma \delta$-T-cell lymphoma. Number of clones ${ }^{* *}$, the minimum number of tumor clones in a patient, based on the number of clonal rearrangements in a single locus and the appearance (changing) of clonal products in various tissues. Cases with appearance (change) of clonal products are underlined. For explanation, see Results and Discussion sections. The total number of clonal rearrangements ${ }^{* *}$, total number of clonal rearrangements (peaks) observed in all tissues examined; nm, no material, nd, no data; doubt, an uncertain picture.

been conducted in the National Hematology Research Center of the Russian Ministry of Health (hereinafter the NHRC).

\section{Patients and samples}

The set of patients consisted of 30 people (15 men and 15 women, median age 56 years $(32-75))$. The disease stage was determined according to the Ann-Arbor classification (1971); bone marrow involvement was considered to be stage IV. Four patients were diagnosed with stage I; four, with stage III; and 22, with stage IV. Lymph nodes were involved in 18 (60\%) patients; bone marrow, in 22 (73\%); spleen, in 14 (47\%); skin, in 5 (17\%); gastrointestinal tract, in 4 (13\%); lungs, in 4 (13\%); tonsils, in 3 (10\%); liver, in $3(10 \%)$; mediastinum, in $2(7 \%)$; meninges (neuroleukemia), in 2 (7\%); mammary gland, in $2(7 \%)$; and soft tissues of the orbit, in $1(3 \%)$ (Table 1). Histological and immunohistochemical studies were performed in the NHRC Department of Pathology; and molecular and genetic studies of clonality, in the NHRC Laboratory of Molecular Hematology.

\section{Isolation of DNA from tissues}

Leukocytes and DNA from blood and bone marrow samples were isolated as described [14]. For isolation of DNA from tissue embedded into a paraffin block, five $5-\mu \mathrm{m}$ sections were collected in Eppendorf tubes. The tissue was dewaxed by heating $[15,16]$. Freshly frozen tissue for DNA extraction was thawed, and a $1 \times 1 \times 1$ mm piece was cut out. DNA was isolated by the method based on tissue dissolution in concentrated ammonia with subsequent neutralization with glacial acetic acid and salting-out of proteins [17]. DNA concentration was determined using a UV spectrophotometer. DNA samples were stored at $-20^{\circ} \mathrm{C}$.

Studies of TCR gene rearrangements by PCR and fragment analysis

T-cell clonality was assessed using multiplex BIOMED-2 primers systems for fragment analysis [13] based on the rearrangements of the TCRG $(\mathrm{V} \gamma-\mathrm{J} \gamma)$ and $T C R B(\mathrm{~V} \beta-\mathrm{J} \beta, \mathrm{D} \beta-\mathrm{J} \beta)$ genes. In the case of $\gamma \delta-\mathrm{T}-$ cell lymphomas, TCRD genes rearrangements were also analyzed. Multiplex amplification of TCRD genes was performed in duplicate tubes according to the BIOMED-2 protocol, Tube A and Tube B, and TCRB gene amplification, in three tubes, Tube A, Tube B, and Tube $\mathrm{C}$ (see description of the reactions in Table 2). Primers produced by Syntol (Russia) were used for amplification of the TCRD, TCRG genes. The reaction mixture in a final volume of $20 \mu$ included 100 ng of DNA, $10 \mu \mathrm{l}$ of a $2 \times$ PCR mixture (PCR Master Mix Promega), and 5 pmol of each primer. TCRB genes were amplified using a commercial TCRB Gene Clonality Assay ABI Fluorescence Detection kit (Invivoscribe Technologies) and AmpliTaq Gold DNA polymerase (Applied Biosystems) according to the manufacturers' instructions. PCR conditions were as follows: pre-dena- 
Table 2. Sets of PCR primers used for the BIOMED-2 protocol for the TCRD, TCRG, TCRB genes

\begin{tabular}{|c|c|c|c|}
\hline $\begin{array}{l}\text { Set of primers } \\
\text { (the name of the } \\
\text { tubes) }\end{array}$ & Forward primers & Reverse primers & Length of the product, bp \\
\hline $\begin{array}{c}T C R D \\
\text { Tube A }\end{array}$ & 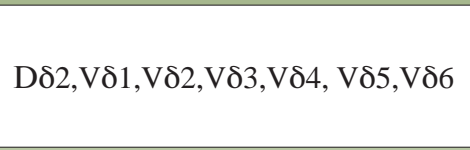 & 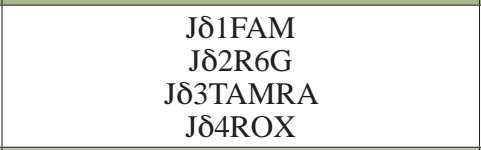 & $130-280$ \\
\hline $\begin{array}{l}\text { TCRD } \\
\text { Tube B }\end{array}$ & 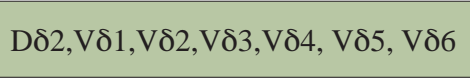 & 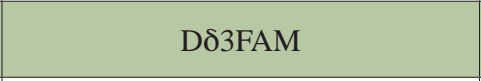 & $190-280$ \\
\hline TCRG & $\mathrm{V} \gamma 1 \mathrm{f}, \mathrm{V} \gamma 9, \mathrm{~V} \gamma 10, \mathrm{~V} \gamma 11$ & $\begin{array}{l}\text { J } \gamma 1 / 2 \mathrm{FAM} \\
\mathrm{Jp} 1 / 2 \mathrm{FAM}\end{array}$ & $100-250$ \\
\hline $\begin{array}{c}\text { TCRB } \\
\text { Tube A }\end{array}$ & $\begin{array}{c}\mathrm{V} \beta 2-\mathrm{V} \beta 24 \\
\text { (23 primers) }\end{array}$ & $\begin{array}{c}\mathrm{J} \beta 1.1-\mathrm{J} \beta 1.6 \mathrm{HEX} \\
\text { (6 primers) } \\
\mathrm{J} \beta 2.2, \mathrm{~J} \beta 2.6, \mathrm{~J} \beta 2.7 \text { FAM (3 primers) }\end{array}$ & $240-280$ \\
\hline $\begin{array}{l}\text { TCRB } \\
\text { TubeB }\end{array}$ & $\begin{array}{l}\mathrm{V} \beta 2-\mathrm{V} \beta 24 \\
\text { (23 primers) }\end{array}$ & $\begin{array}{c}\mathrm{J} \beta 2.1, \mathrm{~J} \beta 2.3, \mathrm{~J} \beta 2.4, \mathrm{~J} \beta 2.5 \text { FAM (4 } \\
\text { primers) }\end{array}$ & $240-280$ \\
\hline $\begin{array}{l}\text { TCRB } \\
\text { TubeC }\end{array}$ & $\mathrm{D} \beta 1, \mathrm{D} \beta 2$ & $\begin{array}{c}\text { J } \beta 1.1-\mathrm{J} \beta 1.6 \mathrm{HEX} \\
\mathrm{J} \beta 2.1-\mathrm{J} \beta 2.7 \mathrm{FAM} \\
(13 \text { primers })\end{array}$ & $\begin{array}{l}170-210(\mathrm{D} \beta 2) \\
290-310(\mathrm{D} \beta 1)\end{array}$ \\
\hline
\end{tabular}

turation at $95^{\circ} \mathrm{C}$ (5 min); 35 cycles at $92^{\circ} \mathrm{C}$ (35 seconds), $60^{\circ} \mathrm{C}$ (35 seconds), $72^{\circ} \mathrm{C}(35)$; and final elongation at $72^{\circ} \mathrm{C}$ (10 min). PCR was performed using an automated DNA Engine thermocycler (BioRad, Hercules, USA).

An automatic ABI PRISM 3130 Genetic Analyzer (Applied Biosystems, USA) was used for the fragment analysis of PCR products. To perform it, $2 \mu \mathrm{L}$ of a 20-fold diluted PCR product was mixed with 10 $\mu \mathrm{L}$ of formamide (Applied Biosystems) and $0.04 \mu \mathrm{L}$ of GeneScan 500-LIS Size Standard (Applied Biosystems). After denaturation at $95^{\circ} \mathrm{C}$ for 3 minutes and subsequent cooling, $10 \mu \mathrm{L}$ of the mixture was added to a well of a 96-well plate and high resolution capillary electrophoresis was performed on a POP-4 polymer (Applied Biosystems). The fluorescence of the amplificates and their profile (length distribution) were analyzed by the GeneMapper software v. 4.0 (Applied Biosystems).

\section{Statistical analysis}

To compare the results obtained by the two methods, the Spearman rank correlation coefficient was calculated using the following formula: $r_{\mathrm{s}}=1-6 \sum \mathrm{d}^{2} /\left(N^{3}-\right.$ $N$ ), where $N$ is the sample size; $\mathrm{d}$ is the difference between the ranks for each member of the sample; and $r_{s}$ is the Spearman coefficient.

\section{RESULTS}

TCR gene clonality was detected in 29 of the 30 patients (97\%): for TCRG genes, in 27 of the 30 (90\%); and for TCRB genes, in 29 of the 30 (97\%). In some PTCL samples, the rearrangement was detected in only one of the loci, TCRG or TCRB, which is due to abnormal differentiation of tumor cells and is often associated with an immature and aberrant immunophenotype. For example, in patient 27 , whose bone marrow had only one clonal $\mathrm{D} \beta-\mathrm{J} \beta$ rearrangement, the surface of the tumor cells did not have CD3, CD5, CD4, or CD8, but only CD2 and CD7. The most likely explanation for the lack of clonal peaks in the study of TCR genes (patient 25) is the small number of tumor cells in the sample (many reactive T-lymphocytes). PCR detected bone marrow involvement or the presence of clonal lymphocytes in the blood in $93 \%$ (25 out of 27 ) of patients (Table 1). The clonal rearrangements in bone marrow were not detected only in patients 25 and 26, for whom clonal peaks were also absent or doubtful in the lymph nodes. Morphological methods failed to detect bone marrow involvement in four patients (№ 16-19), whereas PCR detected clonal cells in their bone marrow. Detection of clonal rearrangements of TCRG genes in the bone marrow or blood is considered to be a poor prognostic factor in PTCL [18]. In most patients, we observed multiple (more than two) clonal rearrangements in one locus. Tumor lymphocytes clone may have a rearrangement on one chromosome (monoallelic rearrangement) or on two homologous chromosomes (biallelic rearrangement). Therefore, only one or two clonal peaks can be detected for each gene (TCRD or $T C R G$ or $T C R B$ ) in one tumor clone.

Additional D $\beta 2-\mathrm{J} \beta$ rearrangement (Fig. 3) is described as an exception [19, 20]. In this case, an additional clonal peak in a range from 170-210 bp was observed in Tube $\mathrm{C}$ during fragment analysis after amplification of TCRB genes (Table 2). 


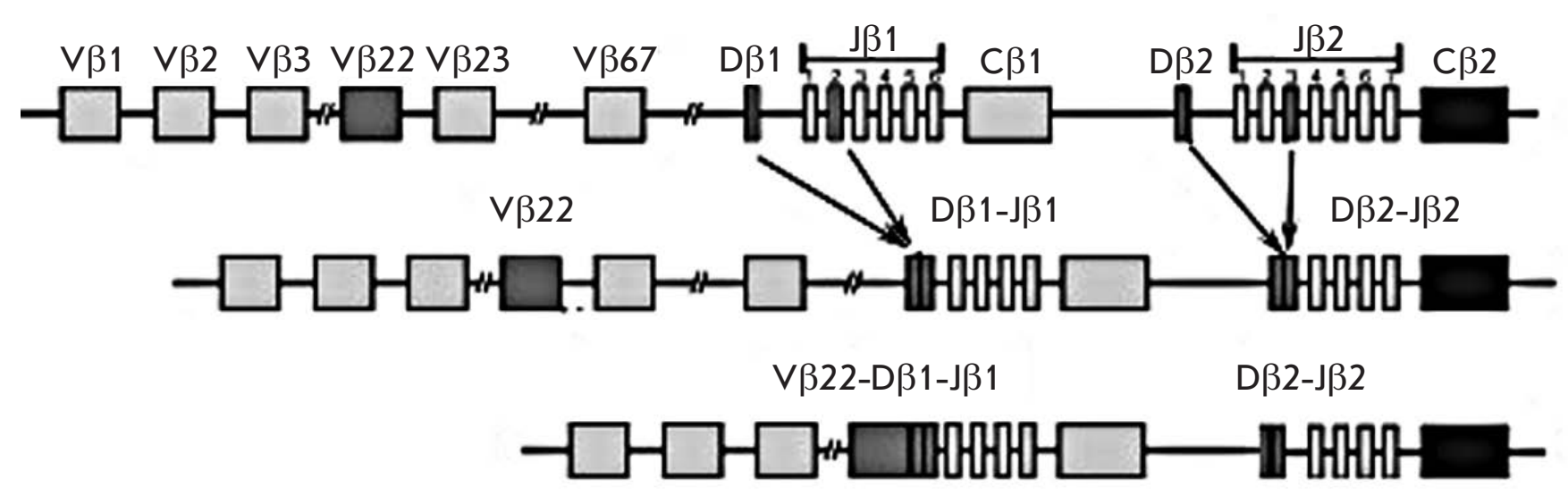

Fig. 3. Additional $D \beta 2-\mathrm{J} \beta$ rearrangement acquisition diagram. Figure shows TCRB locus with $\mathrm{D} \beta 22-\mathrm{D} \beta 1-\mathrm{J} \beta 1$ and $D \beta 2-$ $\mathrm{J} \beta 2$ fusions

In 13 out of the $30(43 \%)$ patients, three or more clonal peaks were detected in one TCR gene locus in at least one tissue (10 patients, in the TCRG locus; 11 , in the TCRB locus). Multiple (three or more) clonal peaks were detected at the same frequency in bone marrow, lymph nodes, and/or spleen (in 10 out of 13 patients). In theory, the "extra" peaks can be attributed to reactive T-cells, but we faced a completely different situation. In $63 \%$ of the patients (15 out of 24 ) in whom we had analyzed several tissues, we observed the appearance of new clonal peaks and new clones in various tissues. The clonal rearrangements reported earlier were either not detected or partially preserved. There was a correlation between observations for the TCRG and $T C R B$ genes: i.e., the appearance of a new clonal peak of TCRG genes was usually accompanied by the identification of a new clonal rearrangement of TCRB genes. This pattern can only be explained by the presence of several tumor clones and their different representations in the tissues and organs. In total, several clones were detected in 19 of the 30 patients (63\%). The number of clones ranged from two to seven (Table 1). There was no correlation with age $(p=0.43)$ or the stage of the disease $(p=0.29)$. Identification of several clones correlated with the number of analyzed tissues $\left(r_{s}=0.6\right.$, $p<0.0005)$. This phenomenon might have been overlooked in other patients due to the low number of investigated tissues. The most representative examples of clonality studies in PTCL are given below.

Patient 11 (Fig. 4). At the time of the diagnosis, $\mathrm{Pa}-$ tient 11 displayed a pattern typical of mature T-cell lymphoma: biallelic rearrangement of TCRG genes (212 and $224 \mathrm{bp}$ ) and complete rearrangement of TCRB genes (Tube B, 262 bp). Bone marrow examination revealed two more clones with incomplete rearrange- ment of TCRB genes (Tube C 187 and 193 bp). Progression of the disease leads to skin lesions, which were accompanied by one or two new clonal rearrangements of TCRG genes (201 bp) and complete rearrangement of TCRB genes (Tube A $254 \mathrm{bp}$ ). Further progress leads to the development of neuroleukemia. The cerebrospinal fluid (CSF) lacked the clones previously detected in the tumor (TCRG 212 and $224 \mathrm{bp}$ ) but contained a clone with rearrangement of TCRG genes, $201 \mathrm{bp}$ in length, and a new clone with rearrangement of TCRG genes, $174 \mathrm{bp}$ in length. After 11 months, the patient underwent splenectomy and liver biopsy due to growing cytopenia. The clonal rearrangement pattern in spleen and liver is identical to the original one in the stomach and lymph node. Therefore, Patient 11 has a total of four rearrangements of the TCRG gene: two full rearrangements of TCRB genes and two incomplete rearrangements of the TCRB gene. The dynamics of appearance of new rearrangements during the progression of the disease indicates five or more different tumor clones.

Patient 9 (Fig. 5). Patient 9 had multiple clonal rearrangements of the TCRG and TCRB genes with a varying presence of clones in different tissues and organs. The primary diagnosis included examination of the blood, bone marrow, tonsil biopsy and lymph node 1 . Five or more rearrangements of the TCRG and $T C R B$ genes were detected in the blood and bone marrow. Tonsil and lymph node 1 contained three and four clonal rearrangements of TCRG, respectively, and four rearrangements of the TCRB gene. Lymph node 2 and skin biopsies were performed with progression of the disease. The lymph node biopsy revealed five rearrangements of the TCRG gene and eight of the TCRB genes. Except for the rearrangements of TCRB (A), 267 
$A$
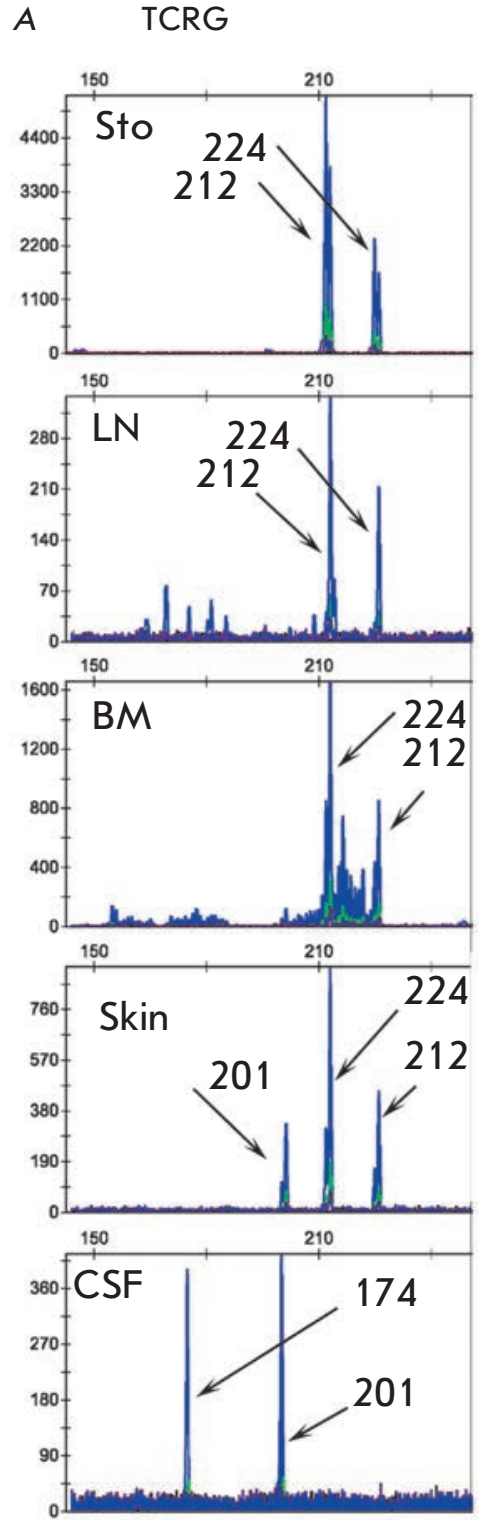

$B$
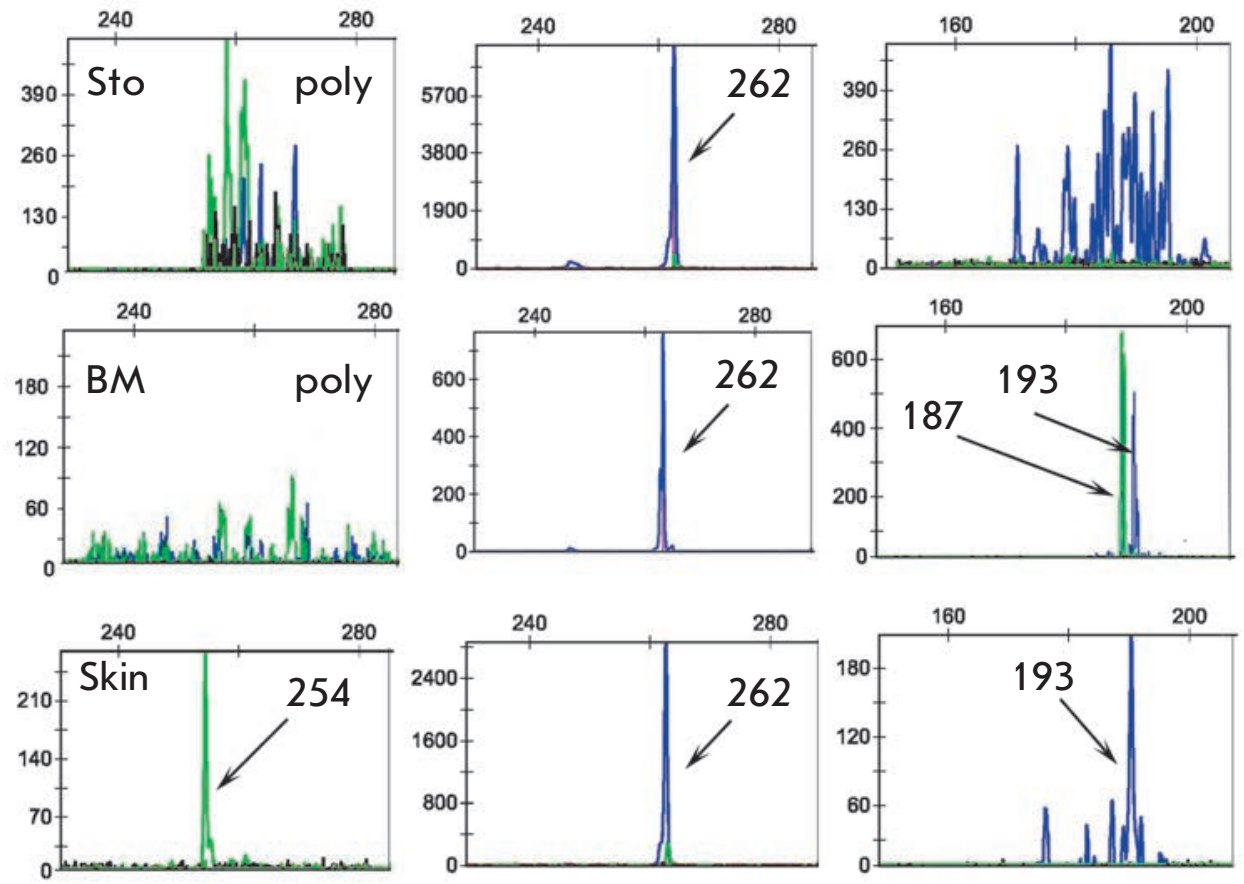

\section{Clonal TCRG and TCRB gene rearrangements}

\begin{tabular}{|c|c|c|c|c|c|c|c|c|}
\hline \multicolumn{2}{|c|}{ Gene } & Sto & LN & BM & Skin & CSF & Spl & Liv \\
\hline \multicolumn{2}{|c|}{ TCRG } & 212 & 212 & 212 & $\underline{201}$ & $\underline{174}$ & 212 & 212 \\
& 224 & 224 & 224 & $\underline{212}$ & $\underline{201}$ & 224 & 224 \\
\hline \multirow{2}{*}{ TCRB } & A & poly & poly & poly & $\underline{254}$ & HA & poly & poly \\
\cline { 2 - 9 } & B & 262 & 262 & 262 & 262 & HA & 262 & 262 \\
\cline { 2 - 9 } & C & poly & poly & $\underline{187}$ & $\underline{193}$ & HA & poly & poly \\
\hline
\end{tabular}

Fig. 4. Clonal TCR rearrangements found in case 11.A, TCRG pattern; B, TCRB pattern; C, Summary Table. Sto, stomach, BM, bone marrow, LN, lymph node, CSF, poly, polyclonal case, NA, no amplification. New clonal products are underlined

bp, and TCRB (B), $262 \mathrm{bp}$, that are present in most tissues simultaneously, other rearrangements of TCRB genes were randomly distributed and belonged to different tumor clones. The data of molecular clonality studies indicate the presence of seven or more tumor clones in this patient.

Patient 8 (Fig. 6). Patient 8 had five different rearrangements of TCRG genes (177, 183, 204, 225, 248 bp) with different clones present in different studied tissues. We found four rearrangements of TCRB: three complete rearrangements (Tubes A and B) and one in- complete D $\beta 2-\mathrm{J} \beta 2$ (Tube $\mathrm{C}$ ). In this case, there was no clear connection between the TCRG and TCRB genes rearrangements. For example, the lymph node 1 and skin predominantly had TCRG gene rearrangements, 183 and $248 \mathrm{bp}$ in size, however, the pattern for TCRB was different. The number of clones in this patient was four or higher, but it is possible that the number of clones could be much higher. For example, the clones with only a TCRG or TCRB rearrangement, or clones with rearrangements of TCRG $177 \mathrm{bp}$ and TCRB 260 bp, TCRG 177 bp and TCRB 189 bp, etc. 
A
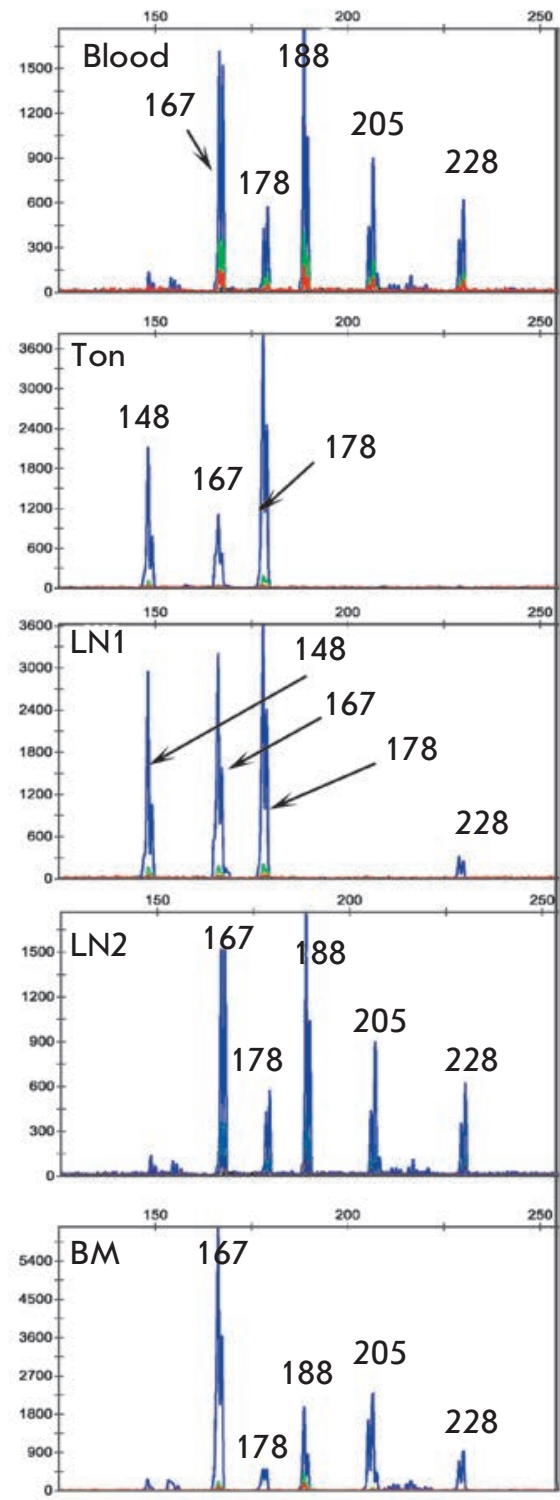

$B$ TCRB Tube A TCRB Tube B
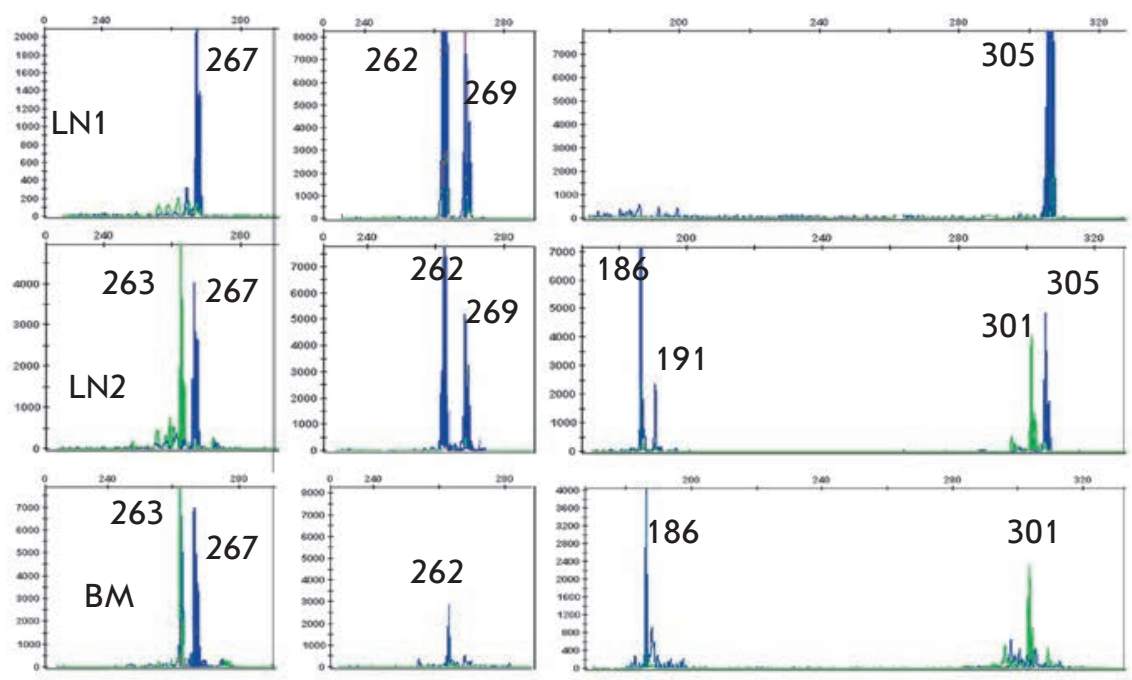

C Clonal TCRG and TCRB gene rearrangements

\begin{tabular}{|c|c|c|c|c|c|c|c|}
\hline Gene & & Blood & Ton & LN1 & LN2 & $B M$ & Skin \\
\hline TCRG & & $\begin{array}{l}167 \\
178 \\
188 \\
205 \\
228\end{array}$ & $\begin{array}{l}148 \\
167 \\
178\end{array}$ & $\begin{array}{l}148 \\
167 \\
178 \\
228\end{array}$ & $\begin{array}{l}167 \\
178 \\
188 \\
205 \\
228\end{array}$ & $\begin{array}{l}167 \\
178 \\
188 \\
205 \\
228\end{array}$ & $\begin{array}{l}162 \\
167 \\
178\end{array}$ \\
\hline TCRB & A & - & 267 & 267 & $\begin{array}{l}263 \\
267 \\
\end{array}$ & $\begin{array}{l}263 \\
267\end{array}$ & HA \\
\hline & B & - & $\begin{array}{l}262 \\
269\end{array}$ & $\begin{array}{l}262 \\
269\end{array}$ & $\begin{array}{l}262 \\
269 \\
\end{array}$ & 262 & 262 \\
\hline & $C$ & - & 305 & 305 & $\begin{array}{l}186 \\
191 \\
301 \\
305\end{array}$ & $\begin{array}{l}186 \\
301\end{array}$ & HA \\
\hline
\end{tabular}

Fig. 5. Clonal TCR rearrangements found in case 9. A, TCRG pattern; B, TCRB pattern; C, Summary table. Ton, tonsil; $B M$, bone marrow; $L N$, lymph node; NA, no amplification

\section{DISCUSSION}

The presence of several tumor clones described in acute lymphoblastic leukemia (ALL) is attributed to an "ongoing" process of rearrangement of immunoglobulins and TCR genes in early progenitor cells [21-24]. Clonal products sequencing during ALL manifestation and in relapse showed that clones with incomplete rearrangements of the TCRD and TCRB genes and their derivatives with complete clonal rearrangements are simultaneously present in ALL. Furthermore, in some cases complete rearrangement is modified. The $V$ gene is replaced with another (upstream) gene or the rearrangement is completely replaced by another one of the upstream $V$ and downstream $J$ genes, i.e. by the genes that are distal to the previous rearrangement. In some cases, there is a deletion and disappearance of the TCR gene rearrangement in relapse.

We believe that the molecular events that occur in ALL can also occur in PTCL. In tumor cells, the control mechanisms which are responsible for preventing further restructuring of a locus after a productive rearrangement are disrupted, which leads to increased 

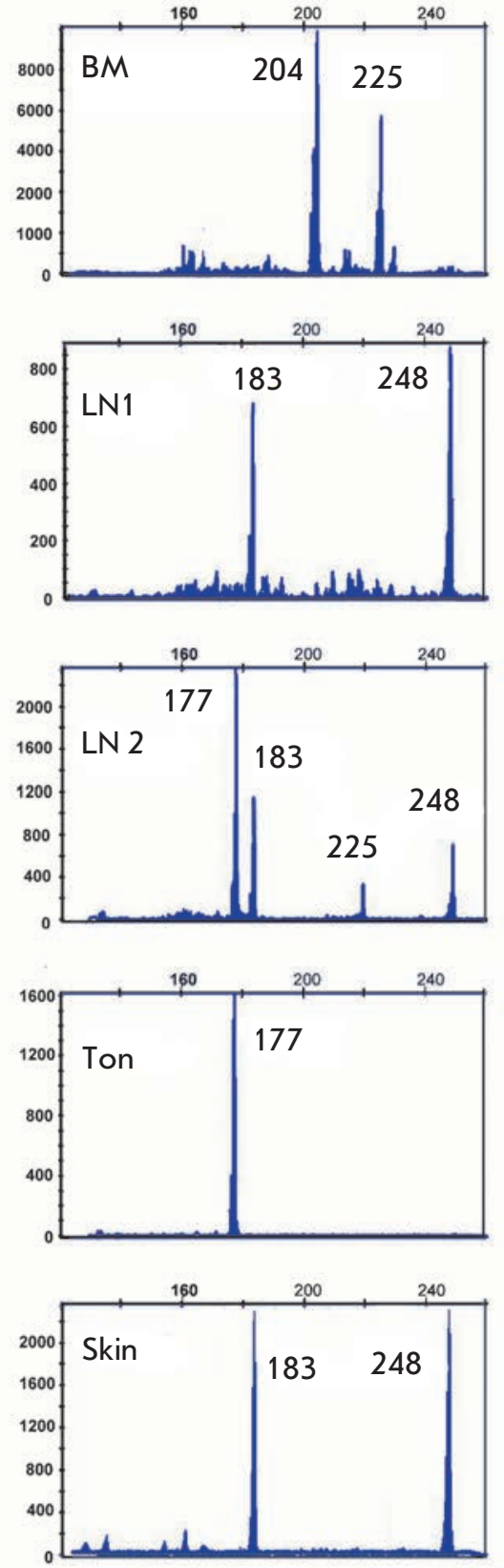
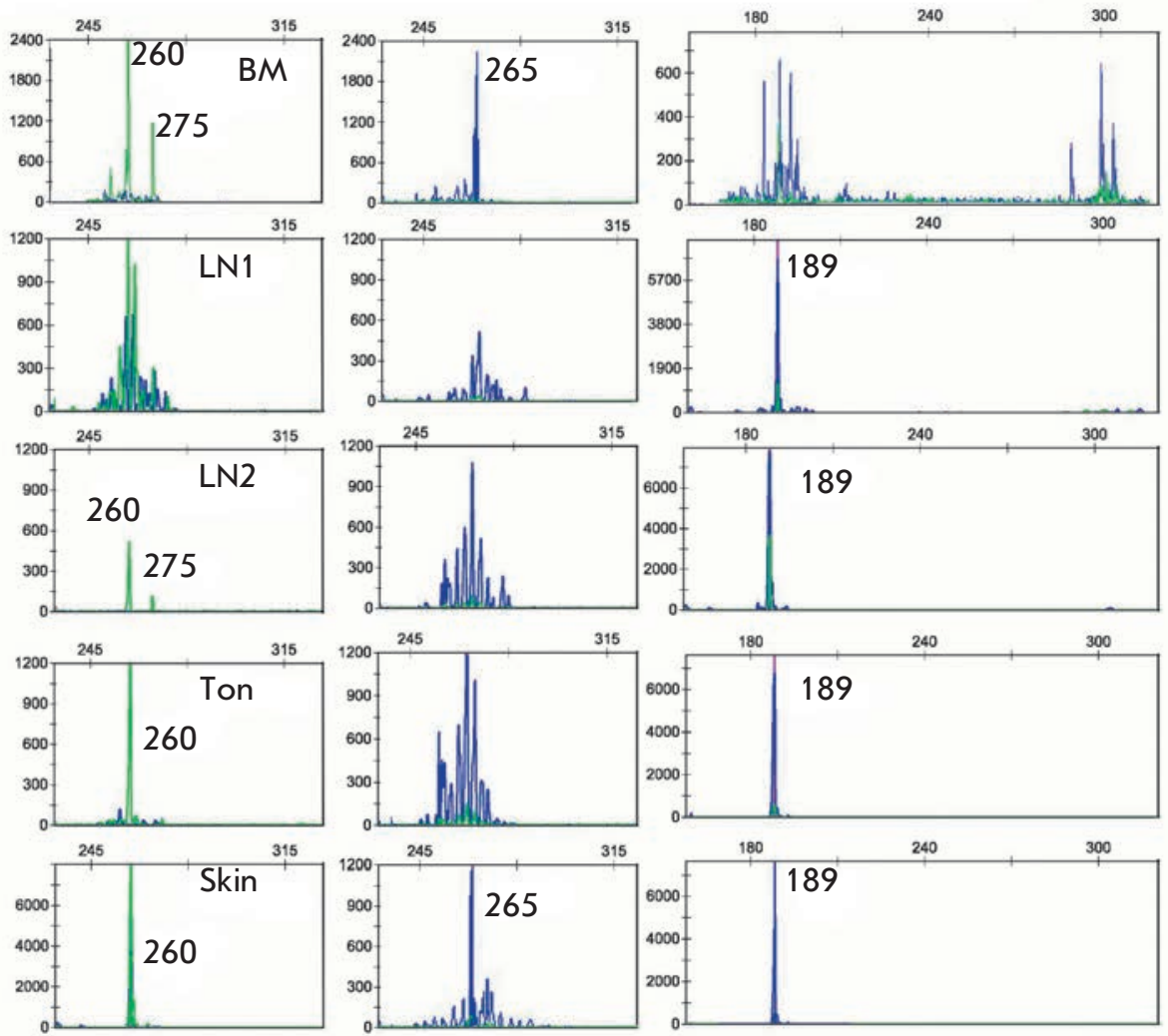

C Clonal TCRG and TCRB gene rearrangements

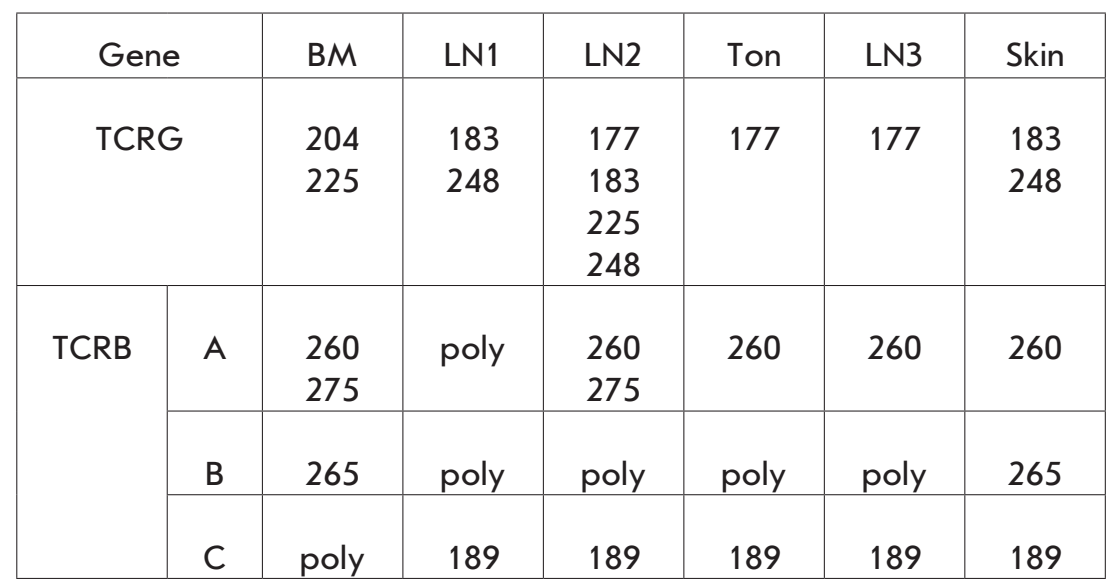

Fig. 6. Clonal TCR rearrangements found in case 8.A, TCRG pattern; B, TCRB pattern; C, Summary table. Ton, tonsil; $B M$, bone marrow; LN, lymph node; poly, polyclonal case

activity of the RAG1 and RAG2 enzymes, changes in chromatin organization, etc. It is possible that in PTCL rearrangements can be replaced with new ones and/or that an incomplete $\mathrm{D} \beta-\mathrm{J} \beta$ one can be replaced with a complete $\mathrm{V} \beta-\mathrm{J} \beta$ one. In addition, there is general chromosomal instability, which can lead to deletions or du- plications of the TCR genes locus. The deletion of the locus may trigger further rearrangements on homologous chromosomes. Complex chromosomal changes, including triploidy, tetraploidy, loss of chromosomes, $7 \mathrm{q}$ trisomy, and translocations involving $T C R$ genes loci (14q11, 7q34-35, 7p13-21) are described in various pe- 
ripheral T-cell lymphomas [25-27]. In any case, clonal rearrangements are common markers that indicate the heterogeneity of the tumor and clonal evolution during the progression of the disease. We have observed "multiclonality" in most patients, but it is unclear whether this phenomenon is present only in PTCL. It is possible that some other lymphomas also have high clonal heterogeneity, but their "visualization" requires different approaches and methods.

\section{CONCLUSIONS}

Studies of TCRG and TCRB genes clonality effectively prove the presence of a tumor in the majority (97\%) of PTCL patients. PCR revealed bone marrow involve- ment and/or presence of clonal lymphocytes in the blood in the majority (93\%) of patients, whereas in morphological studies bone marrow involvement was confirmed only in $73 \%$ of the patients. A specific pattern of rearrangements in PTCL (multiple rearrangements of the TCRG and TCRB genes, loss and gain of new ones, presence of several clones of a tumor) was observed in the majority of patients (63\%) and should certainly be taken into account when using this method for diagnostic purposes. The emergence of new clonal peaks (clones) should not be considered to be the emergence of a new tumor. In addition, multiple rearrangements may interfere with minimal residual disease monitoring in PTCL.

\section{REFERENCES}

1. Swerdlow S.H., Campo E., Harris N.L., Jaffe E.S., Pileri S.A., Stein H., Thiele J., Vardiman J.W. WHO Classification of Tumors of Hematopoietic and Lymphoid Tissues. Lyon: IARC, 2008. V. 2. 439 p.

2. Vose J., Armitage J., Weisenburger D., Savage K., Connors J., Gascoyne R., Chhanabhai M., Wilson W., Jaffe E., Armitage J., et al. // J. Clin. Oncol. 2008. V. 26. № 25. P. 4124-4130. 3. Weisenburger D.D., Savage K.J., Harris N.L., Gascoyne R.D., Jaffe E.S., MacLennan K.A., Rüdiger T., Pileri S., Nakamura S., Nathwani B., et al. // Blood. 2011. V. 117. № 12. P. 3402-3408.

4. De Leval L., Gaulard P. // Histopathology. 2011. V. 58. № 1. P. 49-68.

5. Vinogradova Yu. E., Lutsenko I.N., Samoilova R.S., Selivanova E.I., Zamulaeva I.A., Gretsov E.M., Vorobyov I.A., Kaplanskaya I.B., Ryzhikova N.A., Al-Radi L.S., Gabeeva N.G., Dzhulakyan U.L., Egorova E.K., Margolin O.V., Kremenetskaya A.M., Vorobyov A.I. // Gematologiya i Transfuziologiya. 2009. V. 54. №2. P. 14-18.

6. Vinogradova Y.E., Kaplanskaya I.B., Samoilova R.S., Vorobiev I.A., Zingerman B.V., Sidorova Y.V., Shklovskiy-Kordi N.E., Aitova L.G., Maryin D.C., Vorobiev A.I., et al. // Clin. Med. Insights: Blood Disorders. 2012. № 5. P. 1-13.

7. Brüggemann M., White H., Gaulard P., Garcia-Sanz R., Gameiro P., Oeschger S., Jasani B., Ott M., Delsol G., Orfao A., et al. // Leukemia. 2007. V. 21. № 2. P. 215-221.

8. Tan B.T., Warnke R.A., Arber D.A. // J. Mol. Diagn. 2006. V. 8. № 4. P. 466-475.

9. Sidorova Yu. V., Nikitin E.A., Peklo M., Vlasik T.N., Samoilova R.S., Kravchenko S.K., Melikyan A.L., Vinogradova Yu. E., Pivnik A.V., Sudarikov A.B. // TerArkh. 2003. V. 75. № 7. P. 48-52.

10. Nikitin E.A., Sidorova Yu. V., Ryzhikova N.V., Biderman B.V., Melikyan A.L., VinogradovaYu.E., Al-Radi L.S., Sudarikov A.B. // TerArkh. 2006. V. 78. № 7. P. 52-57.

11. Sidorova Yu. V., Nikitin E.A., Biderman B.V., Groznova A. A., Sorokina T.V., Sudarikov A.B. // Spravochnik Zaveduyushchego KDL 2009. № 6. P. 13-21.

12. Rothenberg E.V., Moore J.E., Yui M.A. // Nat. Rev. Immunol. 2008. V. 8. № 1. P. 9-21.
13. Dongen J.J., Langerak A.W., Bruggemann M., Evans P.A., Hummel M., Lavender F.L., Delabesse E., Davi F., Schuuring E., García-Sanz R., et al. // Leukemia. 2003. V. 17.

№ 12.P. 2257-2317.

14. Sidorova Yu. V., Sorokina T.V., Biderman B.V., Nikulina Ye. Ye., Kisilitchina D.G., Naumova Ye. V., Potchar M. Ye., Lugovskaya S.A., Ivanova V.L., Kovaleva L.G., Ptuschkin V.V., Nikitin Ye. A., Sudarikov A.B. // Klin Lab Diagn. 2011. № 12. P. 22-35.

15. Wu L., Patten N., Yamashiro C.T., Chui B. // Appl. Immunohistochem. Mol. Morphol. 2002. V. 10. № 3. P. 269-274.

16. Coombs N.J., Gough A.C., Primrose J.N. // Nucl. AcidsRes. 1999. V. 27. № 16. e12.

17. Sidorova J.V., Biderman B.V., Nikulina E.E., Sudarikov A.B. // Exp. Dermatol. 2012. V. 21. № 1. P. 57-60.

18. Schützinger C., Esterbauer H., Hron G. // Leuk. Lymphoma. 2008. V. 49. № 2. P. 237-246.

19. Langerak A.W.,Wolvers-Tettero I.L.M.,Van Dongen J.J.M. // Leukemia. 1999. V. 13. № 6. P. 965-974.

20. Groenen P.J., Langerak A.W., van Dongen J.J., van Krieken J.H. // J. Hematop. 2008. V. 1. № 2. P. 97-109.

21. Szczepański T., van der Velden V.H., Raff T., Jacobs D.C., van Wering E.R., Brüggemann M., Kneba M., van Dongen J.J. // Leukemia. 2003. V. 17. № 11. P. 2149-2156.

22. de Haas V., Verhagen O.J., von dem Borne A.E., Kroes W., van den Berg H., van der Schoot C.E. // Leukemia. 2001.

V. 15. № 1. P. 134-140.

23. Szczepański T., Willemse M.J., Brinkhof B., van Wering E.R., van der Burg M., van Dongen J.J. // Blood. 2002. V. 99. № 7. P. $2315-2323$.

24. Germano G., del Giudice L., Palatron S., Giarin E., Cazzaniga G., Biondi A., Basso G. // Leukemia. 2003. V. 17. № 8. P. 1573-1582.

25. Boehm T., Rabbitts T.H. // FASEB J. 1989. V. 3. № 12. P. 2344-2359.

26. Schlegelberger B., Himmler A., Godde E., Grote W., Feller A.C., Lennert K. // Blood. 1994. V. 83. №2. P. 505-511. 27. Gesk S., Martín-Subero J.I., Harder L., Luhmann B., Schlegelberger B., Calasanz M.J., Grote W., Siebert R. // Leukemia. 2003. V. 17. № 4. P. 738-745. 